\title{
Signed Lexical Items in an Afrikaans Oral Residential School for the Deaf
}

\author{
Sonya Warren, B(Log) (Pretoria) \\ Durban School, Psychological Centre, Durban \\ Santie Meyer, M(Log) (Pretoria) \\ H.E.C. Tesner, MA (Pretoria) \\ Department of Speech Pathology and Audiology, \\ University of Pretoria
}

\begin{abstract}
:
The signs for 15 lexical items were video recorded and analyzed for 40 congenitally deaf subjects (hearing loss greater than 91 dB in the best ear) from an Afrikaans oral residential school for the deaf. A uniform and relatively arbitrary sign system was found to be in usage within the school. Comparing these signs with the signs used in an English oral residential school for the deaf, it became apparent that only certain signs for lexical items were similar. Furthermore, a marked difference between the signs for lexical items used by the deaf in the Afrikaans residential school and the "standard South African signs" were found.
\end{abstract}

\section{OPSOMMING}

Die gebare vir 15 leksikale items is op videoband geneem en ontleed vir 40 kongenitaal dowe leerlinge (gehoorverlies groter as 91 dB in die beste oor) in ' $n$ Afrikaanse skool vir gehoorgestremdes. Die leerlinge word deur middel van die orale metode opgelei. Daar is bevind dat daar ' $n$ eenvormige en relatief arbitrêre gebaresisteem in die skool gebruik word. Enkele van die gebare toon ooreenkomste met die wat in 'n soortgelyke skool waar Engels die voertaal is, gebruik word. Daar is ook enkele ooreenkomste tussen die gebare vir leksikale items van die dowes in die Afrikaanse skool en die "standaard Suid-Afrikaanse gebare".

Sign languages as commonly used among the deaf, are highly structured and organized systems and thus allow for communication equal to spoken languages. A sign language' consists of a lexicon, grammatical rules and semantic characteristics, which enables one to express ideas and satisfy communicative needs (Bonvillian, Orlansky and Novack, 1978).

Signs serve as the lexicon of this visibly transmitted language. A single member of a lexicon is a lexical item (i.e. a sign) which in a spoken language would be a word. Many different types of signs are in existence: local, provincial, standard, conservative and puristic (Stokoe, 1976 as cited by Caccamise, Ayers, Finch and Mitchell, 1978).

Analogous to the structure of the phonological system of oral language, are four parameters: hand configuration, hand orientation, movement of the hand and location where these occur, which arise from the patterned movements of the hands (Klima and Bellugi, 1980). These parameters are combined simultaneously to form either iconic signs, which visually resemble the referent, or arbitrary signs, which bear little or no resemblance to the referent (Orlansky and Bonvillian, 1984). Both iconic and arbitrary signs used by different signers are not only non-uniform throughout the world, but are not necessarily standardized within many countries (Battison as cited by Stokoe, 1980a). Caccamise et al. (1978), state that the standardization can only occur through consistency of sign use, that is, through public and institutional acceptance of the same sign, for the same meaning, by different users. To obtain this 'consistency' of use is not easy and often proves impossible, owing to differing sociological, demographical and cultural factors present in a country (Fisher, 1982).

South Africa is a country where the above-mentioned factors are especially apparent. A diverse cultural heritage, as well as demographic and politically induced separateness of its ethnic groups, emphasizes these differences (Penn, Lewis, Greenstein, 1984). These ethnic groups have their own culture, each differing from the other.
It can therefore be assumed that a sign system will develop among the deaf in each ethnic group. Penn et al. (1984) hypothesize that those South African sign languages that exist, contain as rich a vocabulary and arbitrary a structure as any language. However, because sign languages differ just as much as spoken languages differ from one another (Markowicz, 1977, as cited by Musselwhite and St. Louis, 1982) 'consistency' of sign use in this country would be virtually impossible. It has been proposed by Lewis (1983) that because of South Africa's discrete educational policies, the separate signing systems will reflect the social group of those who use them. A study in respect of the English deaf group in Johannesburg was therefore carried out (Greenstein, 1983), to determine whether or not uniform signs were used within an English oral residential school for the deaf, and whether or not there was a divergence from these signs from the proposed 'South African' signs of Nieder-Heitmann (1980). These signs ${ }^{2}$ in the book "Talking to the Dear" are presently being promoted as being representative of the signs used by the majority of the deaf in this country (Rousseau 1980). Results indicate that uniform signs were used in the English oral residential school, as hypothesized. and that $75 \%$ of these did indeed differ from Nieder-Heitmann's (1980) proposed sign system. By attempting to investigate the Afrikaans deaf cultural group's use of sign, this study will also aim at providing further information concerning the use of 'uniform' South African signs.

The purpose of this study is to determine whether or not certain lexical items in the sign lexicon used by the Afrikaans-speaking deaf school child in an Afrikaans oral residential school for the deaf, are uniform and consistently used within the school and to what degree this Afrikaans sign lexicon differs from that of the English culture and the South African signs of Nieder-Heitmann (1980). In this way an indication of the degree to which a

\footnotetext{
' Such a language is American Sign Language (ASL), a bona fide language most widely uséd by the deaf in America.

2 These signs will be referred to as the South African signs.
} 
consistently used uniform sign system exists within South Africa, can be provided.

\section{METHOD}

\section{AIMS}

The following aims were formulated:

a. To describe the signs used by children in an Afrikaans oral residential school for the deaf, determining whether or not the use of the signs described is uniform within the school.

b. To determine whether or not the signs in the Afrikaans residential school for the deaf, differ from those in use at the English oral residential school for the deaf, thus determining whether the nature of the signs is affected by the language culture group (Greenstein, 1983).

c. To determine whether or not the signs used within the school, differ from those proposed by Nieder-Heitmann (1980) to be the standard ${ }^{3}$ South African signs.

\section{SUBJECTS}

For this study forty pupils aged 7 to 19 years were selected from an Afrikaans residential school for the deaf. Profound congenital hearing loss was present in all subjects (hearing level greater than $91 \mathrm{~dB}$ in the best ear). The rationale for studying these subjects is based on evidence that they rely to a greater extent on non-verbal communication than subjects with more residual hearing (Siple et al. 1978a). Subjects with deaf parents were excluded from this study because these parents could influence the vocabulary used by the child.

Furthermore, subjects with other handicaps were also excluded because these handicaps could affect their signing abilities. The subjects selected for this study are presented in Table 1.

\section{Table 1: Description of subjects}

\begin{tabular}{|l|rrrr|}
\hline \multicolumn{1}{|c|}{ Variables } & \multicolumn{5}{c|}{ Age Groups (years) } \\
& $7-9$ & $10-13$ & $14-16$ & $17-19$ \\
\hline Degree of loss: $>91 \mathrm{~dB}(\mathrm{HL})$ & 10 & 10 & 10 & 10 \\
Onset of loss: Congenital & 10 & 10 & 10 & 10 \\
Hearing status of parents: & 10 & 10 & 10 & 10 \\
Normal & 10 & & & \\
Educational environment: & 10 & 10 & 10 & 10 \\
Afrikaans & 10 & 10 & 10 & 10 \\
Residential status: Boarders & 10 & 0 & 0 & 0 \\
Secondary handicaps: None & 0 & 10 & 10 & 10 \\
Intelligence: Normal & 10 & 10 \\
Sex: Male & 5 & 5 & 5 & 5 \\
$\quad$ Female & 5 & 5 & 5 & 5 \\
\hline
\end{tabular}

\section{MATERIAL}

Twelve of the fifteen lexical items were selected from those used by Greenstein (1983) to compare the signs of the Afrikaans and English deaf pupils. These are:

Nouns: $\quad$ hond, mamma, boom

Verbs: bad, spring, sit

Adjectives: $\quad$ geel, oud, bly

Prepositions: op, voor, $n a \ldots$ toe

In addition the following three emotive words were arbitrarily chosen: lag, kwaad, huil (Warren, 1985)

${ }^{3}$ Standard $=$ consistent use of signs (Caccamise, Ayers, Finch and Mitchell, 1978).

Die Suid-Afrikaanse Tydskrif vir Kommunikasieafwykings, Vol. 33, 1986

\section{REPRESENTATION OF TEST MATERIAL}

A clear, colourful picture, representing each lexical item was used to elicit a response. Below the picture was the printed form of the word in isolation as well as in a sentence in dark block lettering underneath the picture-word card (Warren, 1985).

\section{PROCEDURE}

A quiet, well-lit room in the school was used. Instructions were given orally, in natural gestures and in sign, by the investigator. The subjects had to sign the word represented by the pictureword card.

Subjects were then individually tested to ensure that they could not influence one another's use of signs.

Subjects were filmed so that the whole body of the subject was video taped, capturing the total movement involved in producing the sign (Warren, 1985).

\section{SCORING PROCEDURE}

For the analysis of data, the three parameters as described by Stokoe (1980b) were used, namely: DEZ, SIG \& TAB.

In addition to these three ciassic parameters, orientation was analysed as a fourth parameter as suggested by Battison, Markowicz and Woodward (1975, as cited by Daniloff and Vergara, 1984). Orientation is important in sign formation, as it distinguishes between minimal pairs of signs. Signs were analyzed according to:

a. Designation - DEZ - the distinctive handshape used to make the sign e.g. flat hand. A list of handshapes used by the subjects in this study were obtained from NiederHeitmann's book 'Talking to the Deaf' $(1980$, p. 54) as a comparison of the signs of Afrikaans subjects to the South African signs was being made, and a common classification system was needed. Any handshapes used by the subjects, and not listed by Nieder-Heitmann (1980) were obtained from Klima and Bellugi (1980).

b. Signation - SIG - the movement involved in making the sign, e.g. circular.

c. Tabulation - TAB - the location where a sign begins and ends in relation to the signer's body. Termed "place of articulation' e.g. chest.

d. Orientation - ORIENT - planes of the palms of the hand, e.g. palm up.

\section{RESULTS}

Table 2 provides a clear description of the signs consistently used by the majority ${ }^{4}$ of Afrikaans subjects - $50 \%$ being a significant majority according to Penn and Saling ( 1983 as cited by Greenstein, 1983). Fourteen of the fifteen signs have been described according to the four parameters dez, sig, tab (Stokoe, 1980b) and orient (Markowicz and Battison, 1975 as cited by Daniloff and Vergara 1984). One sign, 'in front of' is discussed in Table 3, as no single sign is used by the major ity for this lexical item. The percentage of subjects using the sign has been provided to indicate the extent to which each sign is used by the subjects.

\footnotetext{
${ }^{4}$ Signs used by the majority in the school will be referred to as uniform signs.
} 
Table 2: A description of the signs used by the majority of subjects in the Afrikaans oral residential school for the deaf

\begin{tabular}{|c|c|c|c|c|c|}
\hline Word & $\%$ of ss & Dez & Sig & Tab & Orient \\
\hline Dog (Hond) & $100 \%$ & $\begin{array}{l}\text { Compressed } \\
\text { hand } \\
\end{array}$ & Opens and closes & Lower face & $\begin{array}{l}\text { Vertical - unilateral } \\
\text { opposite }\end{array}$ \\
\hline $\begin{array}{l}\text { Mommy* } \\
\text { (Mamma) }\end{array}$ & $92,5 \%$ & Claw hand & $\begin{array}{l}\text { Move hand across chest } \\
\text { L-R, R-L }\end{array}$ & Chest & Vertical - toward body \\
\hline Tree (Boom) & $95 \%$ & $\begin{array}{l}\text { Cupped hands } \\
\text { (bilateral) }\end{array}$ & $\begin{array}{l}\text { Finger tips together move } \\
\text { apart in a circular shape join- } \\
\text { ing once more at wrists }\end{array}$ & $\begin{array}{l}\text { Fingers } \\
\text { Wrist }\end{array}$ & $\begin{array}{l}\text { Vertical - bilateral } \\
\text { opposite }\end{array}$ \\
\hline Yellow (Geel) & $85 \%$ & Broad U-hand & Wrist action & $\begin{array}{l}\text { Opening of ear } \\
\text { on same side }\end{array}$ & $\begin{array}{l}\text { Vertical - unilateral } \\
\text { opposite }\end{array}$ \\
\hline Old (Oud) & $60 \%$ & Crooked fingers & $\begin{array}{l}\text { Move finger slowly down } \\
\text { cheek }\end{array}$ & $\begin{array}{l}\text { Cheek on } \\
\text { same side }\end{array}$ & Vertical - away from body \\
\hline Happy* (Bly) & $57,5 \%$ & $\begin{array}{l}\text { Flat hands } \\
\text { (bilateral) }\end{array}$ & Clap hands together & Neutral & $\begin{array}{l}\text { Vertical — bilateral } \\
\text { opposite }\end{array}$ \\
\hline Bath (Bad) & $95 \%$ & Spread hand & Rub hand in circular motion & $\begin{array}{l}\text { Lower chest } \\
\text { Abdomen }\end{array}$ & Vertical - toward body \\
\hline Jumping (Spring) & $72 \%$ & $V$ hand & $\begin{array}{l}\text { Raise hand vertically from } \\
\text { palm of opposite hand }\end{array}$ & $\begin{array}{l}\text { Palm of opposite } \\
\text { hand }\end{array}$ & $\begin{array}{l}\text { Vertical - unilateral } \\
\text { body }\end{array}$ \\
\hline Sitting (Sit) & $77,5 \%$ & Fist hand & $\begin{array}{l}\text { Move hand downward to } \\
\text { strike palm of opposite hand }\end{array}$ & $\begin{array}{l}\text { Palm of opposite } \\
\text { hand }\end{array}$ & $\begin{array}{l}\text { Vertical - unilateral } \\
\text { opposite }\end{array}$ \\
\hline On $(O p)$ & $72,5 \%$ & Flat hand & Move hand straight down & $\begin{array}{l}\text { Neutral } \\
\text { Abdomen }\end{array}$ & Horizontal - palm down \\
\hline In front (Voor) & \multicolumn{5}{|c|}{ Minority use - see Table 3} \\
\hline To $(\mathrm{Na} \ldots$ toe $)$ & $50 \%$ & $\begin{array}{l}\text { First finger } \\
\text { (bilateral) }\end{array}$ & $\begin{array}{l}\text { Move Ist finger of dominant } \\
\text { hand along side of opposite } \\
\text { lst finger }\end{array}$ & $\begin{array}{l}\text { Side of opposite } \\
\text { finger }\end{array}$ & Horizontal - palm down \\
\hline Laugh (Lag) & $67,5 \%$ & $\begin{array}{l}\text { Clawed hand } \\
\text { (bilateral) }\end{array}$ & $\begin{array}{l}\text { Move hand } L / R-R / L \text { in } \\
\text { front of }\end{array}$ & Lower face & Vertical - toward body \\
\hline Cross (Kwaad) & $82,5 \%$ & $\begin{array}{l}\text { Clawed hands } \\
\text { (bilateral) }\end{array}$ & No movement & Cheeks & Vertical - toward body \\
\hline \multirow[t]{2}{*}{ Cry* (Huil) } & $85 \%$ & $V$ hand & $\begin{array}{l}\text { Move fingers straight } \\
\text { down cheeks }\end{array}$ & Cheeks & Vertical - toward body \\
\hline & $\bar{x}=73 \%$ & & & & \\
\hline
\end{tabular}

$x=$ The average number of subjects using the sign system

*Signs considered to have a certain amount of iconicity

As is evident from Table 2, the sign for the lexical item 'dog' was the only sign consistently used by $100 \%$ of the subjects. Ten of the fifteen signs were used by more than $70 \%$ of the subjects, while four of the signs, i.e. 'happy', 'to', 'laugh' and 'old' were used by $50 \%$ or more of the subjects.

It was hypothesized that a sign system would be in use at the Afrikaans oral residential school for the deaf. It is apparent from the results in Table 2 that a certain uniform and largely arbitrary sign system is in existence within the school. It is considered uniform as most of the signs are consistently used by the majority of subjects. These signs which serve as a means of communication amongst the subjects, do not appear to be idiosyncratic to each individual signer, but have rather become a system commonly used by the majority of the subjects. This is in agreement with Baker and Cokely's (1980) proposal that the members of a community must agree on the meaning of symbols and the manner in which they are used for effective communication. It is apparent that the above-mentioned activities have taken place amongst the Afrikaans subjects, owing to the fact that $73 \%$ (see Table 2) of the subjects used the same signs for the representation of certain lexical items.

Many of the signs in Table 2 are also considered arbitrary as they do not visually represent the referent e.g. 'yellow'. However, Baker and Cokely (1980) state that degrees of arbitrariness exist where the sign, although largely arbitrary, has a certain degree of iconicity, i.e. relatively arbitrary. These signs are indicated in Table 2 with the use of an asterisk e.g. "mommy". 
Table 3: A description of signs used by a minority of the subjects

\begin{tabular}{|c|c|c|c|c|c|}
\hline Word & $\%$ of ss & Dez & Sig & Tab & Orient \\
\hline Happy (Bly) & $22,5 \%$ & $\begin{array}{l}\text { Flat hands } \\
\text { (bilateral) }\end{array}$ & Clap hands together & $\begin{array}{l}\text { Palm of opposite } \\
\text { hand }\end{array}$ & Horizontal - palm down \\
\hline $\begin{array}{l}\text { Jumping* } \\
\text { (Spring) }\end{array}$ & $15 \%$ & $\begin{array}{l}\text { Flat hands } \\
\text { (bilateral) }\end{array}$ & $\begin{array}{l}\text { Raise hands upwards. Simu- } \\
\text { late jumping movement of legs }\end{array}$ & Side of body & Horizontal - palm down \\
\hline $\begin{array}{l}\text { Sitting* } \\
\text { (Sit) }\end{array}$ & $15 \%$ & $\begin{array}{l}\text { Flat hands } \\
\text { (bilateral) }\end{array}$ & $\begin{array}{l}\text { Move hands downwards. } \\
\text { Simulate sitting movement } \\
\text { by bending knees }\end{array}$ & Side of body & Horizontal - palm down \\
\hline On $(O p)$ & $17,5 \%$ & $\begin{array}{l}\text { Flat hand } \\
\text { (bilateral) }\end{array}$ & Clap hands together & $\begin{array}{l}\text { Palm of opposite } \\
\text { hand }\end{array}$ & Horizontal - palm down \\
\hline \multirow[t]{2}{*}{$\begin{array}{l}\text { In front of } \\
\text { (Voor) }\end{array}$} & $\begin{array}{l}42,5 \% \\
\text { a. }\end{array}$ & Cupped hand & $\begin{array}{l}\text { Move hand forward in semi- } \\
\text { circle away from chest }\end{array}$ & Chest neutral & Vertical - toward body \\
\hline & $\begin{array}{l}35 \% \\
\text { b. }\end{array}$ & First finger & $\begin{array}{l}\text { Point finger forward }- \text { wrist } \\
\text { of dominant hand bangs } \\
\text { against opposite wrist }\end{array}$ & Wrists & Vertical - Away from body \\
\hline \multirow[t]{2}{*}{ To* (Na..toe) } & $\begin{array}{l}27,5 \% \\
\text { a. }\end{array}$ & Fist hand & $\begin{array}{l}\text { Move hand outwards in } \\
\text { bold movement }\end{array}$ & Chest & $\begin{array}{l}\text { Vertical }- \text { unilateral } \\
\text { opposite } \ldots \ldots \ldots \ldots\end{array}$ \\
\hline & $\begin{array}{l}20 \% \\
\text { b. }\end{array}$ & Fist hand & Point finger & $\begin{array}{l}\text { In front } \\
\text { Neutral region }\end{array}$ & $\begin{array}{l}\text { Vertical - unilateral } \\
\text { opposite }\end{array}$ \\
\hline Laugh* & $15 \%$ & $\begin{array}{l}\text { Flat hands } \\
\text { (bilateral) }\end{array}$ & $\begin{array}{l}\text { Hand hold stomach -. slight } \\
\text { move up and down }\end{array}$ & Neutral & Vertical - toward body \\
\hline \multirow[t]{3}{*}{ Cry* (Huil) } & $10 \%$ & $\begin{array}{l}\text { First finger } \\
\text { (bilateral) }\end{array}$ & $\begin{array}{l}\text { Move fingers straight } \\
\text { down cheeks }\end{array}$ & Cheeks & Vertical - toward body \\
\hline & $x=6 \%$ & \multicolumn{4}{|c|}{ Percentage of subjects using the iconic* signs } \\
\hline & $x=15 \%$ & \multicolumn{4}{|c|}{ Percentage of subjects using the minority system of signs } \\
\hline
\end{tabular}

*An asterisk marks the signs that are largely iconic.

Table 3 indicates the signs which are neither idiosyncratic to just one individual signer, nor representative of a majority use, but are, however, used by a minority, i.e. less than $50 \%$ of the subjects. The description of sign follows the same format as that used in Table 2, while an asterisk marks those signs that appear to be iconic.

Pertinent to Table 3 is the fact that all the signs were used by a minority of subjects - appearing to be less than $30 \%$ in all cases except for 'in front of'. For the lexical item 'in front of', two differing signs, each used by a minority of subjects $(42,5 \%$ and $35 \%$ respectively) were elicited (see Table 3 ). The sign for in front of (a), subjectively viewed, appears motorically easier and slightly more iconic than 'in front of (b). Since the lexical items that could be influenced by the context e.g. 'on', were placed in an appropriate sentence, it is felt that the own interpretation of the context by the subjects did not influence the form of the sign. (For example, "He sits on the chair"). It therefore appears that two signs are in use at the Afrikaans oral residential school for the Die Suid-Afrikaanse Tydskrif vir Kommunikasieafwykings, Vol. 33, 1986 deaf, for the lexical item 'in front of:

An issue of importance is the fact that $50 \%$ of the signs - five of the ten in Table 3 - are iconic e.g. 'sitting' - (indicated by an asterisk) while the remaining five are relatively arbitrary. Although Table 3 indicates minority use, at least $10 \%$ of the subjects used the sign in each case. It is therefore apparent that these signs are not idiosyncratic to each individual, but rather serve as a communication system.

Thus it is evident that within this oral school for the deaf a uniform sign system used by a majority, as well as certain signs by the minority, $(\bar{x} 15 \%)$ are in existence. The uniform system shows consistent use by $73 \%$ of the subjects. This is in accordance with Lunde (as cited by Stokoe, 1980a) who states that although oral schools emphasize speech reading and speech, the fact is that the deaf, as a group, use sign language amongst themselves.

2. Differences in structure of the signs used in the English and Afrikaans oral residential school for the deaf. 
Table 4: The variations across the four parameters which occur in the signs of the English and Afrikaans subjects

\begin{tabular}{|l|c|c|c|c|c|c|}
\hline Word & Dez & Sig & Tab & Orient & $\%$ Afr ss & $\%$ Eng ss \\
\hline Dog & $\mathrm{x}$ & $\mathrm{x}$ & $\mathrm{x}$ & $\mathrm{x}$ & & $95 \%$ \\
Mommy & $\mathrm{x}$ & & & & & $77,5 \%$ \\
Tree & $\mathrm{x}$ & $\mathrm{x}$ & $\mathrm{x}$ & $\mathrm{x}$ & & $80 \%$ \\
Yellow & $\mathrm{x}$ & & $\mathrm{x}$ & $\mathrm{x}$ & & $92,5 \%$ \\
Old* & & & & & $60 \%$ & $92,5 \%$ \\
Happy* & & & & & $57,5 \%$ & $92,5 \%$ \\
Bathing & & $\mathrm{x}$ & & & & $80 \%$ \\
Jumping & & & $\mathrm{x}$ & & & $70 \%$ \\
Sitting & $\mathrm{x}$ & $\mathrm{x}$ & $\mathrm{x}$ & $\mathrm{x}$ & & $90 \%$ \\
On & & $\mathrm{x}$ & $\mathrm{x}$ & & $17,5 \%$ & $50 \%$ \\
In front of & \multicolumn{7}{|c|}{ Extreme variations of English signs } \\
To & $\mathrm{x}$ & $\mathrm{x}$ & $\mathrm{x}$ & $20 \%$ & $87 \%$ \\
\hline
\end{tabular}

* = Signs are the same $\quad x=$ Variation in parameter

Table 4 is a comparison of the signs used by the majority of subjects in the Afrikaans school and those used by the majority of subjects in the English school. The signs have been analyzed according to the parameters dez, sig, tab and orient. Notable differences between the two sets of signs are indicated by a cross. The second to last column from the right indicates the percentage of Afrikaans subjects using the signs that are used in the English oral residential school, while the last column in Table 4 indicates the percentage of English subjects using each sign of the sign system, unique to the English oral residential school for the deaf. The sign for 'in front of could not be compared, as Greenstein (1983) could also not determine a definite use of sign by a majority, for this lexical item.

The results in Table 4 can be discussed after the division of signs has been explained. After researching the development of signs it was evident that there are differences between the younger and older subject's signs. Greenstein (1983) noted that a development of certain signs (from the iconic to the more arbitrary forms) was evident. Both the iconic and relatively arbitrary signs were treated as being part of a uniform system. In this study the signs were subdivided into the relatively iconic (developing signs, marked by an asterisk in Table 3) and relatively arbitrary levels (see Table 2). For comparison of the use of iconic and arbitrary signs by different age groups, the reader is referred to Greenstein (1983) and Warren (1985). Although not proven, it is felt that the younger subjects will acquire the adult form of the sign (Bornstein, 1978) (i.e. the more arbitrary uniform sign system). For this reason only the relatively arbitrary sets of signs are compared with Greenstein's (1983) results.

Table 4 illustrates that only in two cases the same signs were used by the majority of English and Afrikaans subjects; these were the signs for 'old' and 'happy'. The four signs 'dog', 'tree', 'sitting' and 'to' show a difference across all four parameters indicating an extreme variation for these lexical items in the two sets of signs. The remaining five signs 'mommy', 'yellow', 'bathing', 'jumping' and 'on' show at least one parametric variation.

Although the uniform signs of the Afrikaans subjects for 'on' differed from the sign of the English subjects by three parameters, a minority of Afrikaans subjects, i.e. 17,5\% did use the sign used by $50 \%$ of the English subjects.
Similarly, $20 \%$ of the Afrikaans subjects used the same sign for 'to' as was used by $87 \%$ of the English subjects. It must be noted that whereas the signs for 'on' and 'to' were used by a majority in the English school, they were only used by a minority in the Afrikaans school. The sign for the lexical item 'jumping' used by the Afrikaans subjects, was found to vary from the sign used by the English subjects, with 'palm up' as opposed to a 'palm down' orientation of the non-dominant hand (see Appendix). Although the three parameters dez, sig and orient correlated, the sign differed because of tabulation.

The sign of the Afrikaans subjects for 'bathing', differed only in 'movement' from the otherwise correlate English sign, while 'mommy' differed only through 'handshape' variation.

It was hypothesized that the signs used by the majority of subjects in the Afrikaans oral residential school for the deaf, would differ from the signs described to be of uniform use (of the majority) in the English oral residential school. The results therefore support the hypothesis that although both schools are using a uniform system of signs, the majority of these signs differ between the two schools. It has been said that children in a given school will invent and utilize signs not found elsewhere (Cokely and Gawlick, 1974 as cited by Bornstein, 1978). Bearing in mind that sign language has never been formally taught in White South African schools, it can therefore be expected that the pupils in both the English and Afrikaans schools have devised their own system of signs.

The fact that the English and Afrikaans groups are representative of different cultures (Baker and Cokely, 1980) could explain these differences. Furthermore, these differences could also be attributed to geographic areas. This is in accordance with Markowicz (1980) who states that in different geographical areas different signs are sometimes used to represent the same thing.

3. DIFFERENCES IN STRUCTURE OF THE SOUTH AFRICAN SIGNS AND THE SIGNS USED IN THE AFRIKAANS ORAL RESIDENTIAL SCHOOL FOR THE DEAF

Table 5: Differences across the parameters occurring in two sets of signs

\begin{tabular}{|c|c|c|c|c|c|}
\hline Word & Dez & Sig & $\mathrm{Tab}$ & Orient & $\%$ Afr ss \\
\hline Dog & $\mathrm{x}$ & $\mathrm{x}$ & $x$ & $\mathrm{x}$ & 1 \\
\hline Mommy a) & $\mathrm{x}$ & $x$ & $\mathrm{x}$ & & \\
\hline b) & $x$ & & $\mathrm{x}$ & $\mathrm{x}$ & \\
\hline Tree a) & $x$ & $x$ & $x$ & $x$ & $\vdots$ \\
\hline b) & $x$ & $x$ & $\mathrm{x}$ & $x$ & \\
\hline Yellow & $x$ & $x$ & $x$ & $x$ & \\
\hline •Old & & & & & $60 \%$ \\
\hline Happy & & & & $\mathrm{x}$ & $22 ; 5 \%$ \\
\hline Bathing & $\mathrm{x}$ & $x$ & $x$ & & $72 \leq 0 \pi$ \\
\hline *Jumping & & & & & $72,5 \%$ \\
\hline Sitting & $\mathrm{x}$ & $\mathrm{x}$ & $\mathrm{x}$ & $x$ & \\
\hline On & $\mathrm{x}$ & $\mathrm{x}$ & $x$ & & \\
\hline In front of a) & $\mathrm{x}$ & $\mathrm{x}$ & $\mathrm{x}$ & & \\
\hline b) & $\mathrm{x}$ & $\mathrm{x}$ & $\mathrm{x}$ & $\mathrm{x}$ & \\
\hline To & $\mathrm{x}$ & $\mathrm{x}$ & $\mathrm{x}$ & $x$ & \\
\hline $\begin{array}{l}\text { Percentage of } \\
\text { South African }\end{array}$ & $\begin{array}{l}\text { rika } \\
\text { yns }\end{array}$ & & & & $13 \%$ \\
\hline
\end{tabular}

* = Signs are the same $x=$ Variation in parameter

a) and $b$ ) $=$ Two varying SA signs for the same lexical item.

Table 5 indicates the variations across the four parameters (i.e. dez, sig, tab and orient of signs) which occur between the South 
African signs and the uniform signs used by the majority of subjects in the Afrikaans oral residential school for the deaf. The analysis follows the same format as that of Table 4 . The far right hand column indicates the number of Afrikaans subjects using the South African signs. For a detailed description of the differences in the two sets of signs refer to the Appendix.

In Table 5 it is evident that, of the twelve signs used by the majority of Afrikaans subjects, only two, namely 'jumping' $* 72,5 \%)$ and 'old' $(60 \%)$ correlate exactly with the South African signs, for the representation of the same lexical items. The signs of the Afrikaans subjects for 'tree' (b), 'dog', 'yellow', 'sitting', 'in front of (b) and 'to' show variations across all four parameters and therefore have no correlation with South African signs i.e. 'mommy' (a and b), 'tree' (a), 'bathing', 'on', 'in front of', while the sign for 'happy' is the only sign which correlates across three parameters with the South African signs. Divergence is evident in the fourth parameter - orientation. The South African sign for "happy' was, however, used by a minority $(22.5 \%)$ of the Afrikaans subjects, correlating across all four parameters because of orientation being 'palm down' as opposed to bilateral opposite which was used by the majority of Afrikaans subjects.

The results of Table 5 indicate that minority of subjects in the Afrikaans oral residential school for the deaf are using the South African signs i.e. 13\%. This clearly shows that within this school a sign system which differs from that of the proposed South African signs of Nieder-Heitmann (1980) is in existence. Only one South African sign 'old' is used consistently by both English and Afrikaans subjects and appears to be the only uniform South African sign of the twelve lexical items.

Rousseau (1980) describes the signs presented in NiederHeitmann's book as a systematized language system, incorporating the signs commonly used by the deaf in South Africa. With these significant differences present it is evident that the validity of Rousseau's (1980) proposal could be queried.

Furthermore, consistency is recognized as a critical factor, the basic premise upon which standardisation rests (Caccamise et al. 1978). Yet, it appears from the above results that the South African signs are not consistently used by subjects to represent the lexiçal items tested.

\section{CONCLUSIONS}

The findings support the hypothesis that a uniform and relatively arbitrary sign system is in existence within the Afrikaans oral residential school for the deaf. The majority of subjects have a sign system which is not idiosyncratic, but is representative of the group studied as a whole. This is in accordance with literature where it is suggested that children in an oral school utilize a sign language amongst themselves (Lunde as cited by Stokoe, 1980b). Although the white deaf population in this country are not taught sign language, they appear to 'turn quite naturally to their own language' (Furth cited by Markowicz, 1980).

On comparison of the results of this study with an investigation carried out on English subjects in an English oral residential school for the deaf (Greenstein, 1983) it was evident that single lexical items were similar. However, in most cases the signs of the Afrikaans subjects were part of a sign system in existence within the Afrikaans oral residential school, which is largely unique to the school. This is in accordance with Cicoural (1978) who notes that a variety of sign forms emerge among signers of differing educational backgrounds.

The results indicate that the subjects in an Afrikaans oral residential school for the deaf - a subgroup of the South African deaf culture - did not make consistent use of the signs proposed by Nieder-Heitmann (1980) to be representative of all signs used by various ethnic groups in South Africa. The signs showed a marked difference from one another. This investigation therefore supports Lewis' (1983) hypothesis that deaf populations in the country, who stem from discrete language and educational backgrounds, will exhibit divergence from the hypothesized standard sign system.

This study is an important introductory contribution with regard to the investigation of the sign lexicon used by subjects in an Afrikaans school for the deaf and adjunct to the study carried out by Penn et al. (1984). With the exception of these results very little research is available regarding this specific sign system. It is an important research area as Stokoe (1980b, p126) states: 'Sign languages generally and Sign in particular make excellent objects for scientific study ... for Sign is a language which can make a deaf person a sharer in culture and also a member of a specific group with its own self awareness and pride.' This is specifically relevant in the demographically diverse multi-cultural situation in South Africa.'

\section{REFERENCES}

Baker, C. and Cokely, D. American Sign Language: A Teacher's Resource Text on Grammar and Culture. T.J. Publishers, Inc., Maryland, 1980.

Bonvillian, J.D., Orlansky, M.D. and Novack, L.L. Developmental Milestones, Sign Language Acquisition and Motor Development. Child Development, VI. 54, 1435-1445, 1978.

Bornstein, H. Sign Language in the Education of the Deaf. In: I.M. Schlesinger and L. Namir (eds) Sign Language of the Deaf. Academic Press, Inc. New York, 1978.

Caccamise, F., Ayers, R., Finch, K., and Mitchell, M. Signs and Manual Communications Systems: Selection, standardization and Development. American Annals of the Deaf, Vol 123, 887-901, 1978.

Cicoural, A.V. Sociolinguistic Aspects of the Use of Sign Language. In: I.M. Schlesinger and L. Namir (eds.) Sign Language of the Deaf. Academic Press, Inc., New York, 1978.

Daniloff, J. and Vergara, D. Comparison Between the Motoric Constraints for Amer. Ind. and A.S.L. Sign Formation. Journal of Speech and Hearing Research. No. 27, 70-76, 1984.

Fisher, S. Sign Language and Manual Communication. In: G.G. Walter and R.L. Whitehead. Deafness and Communication; Assessment and Training. Williams and Wilkins, Baltimore, U.S.A., 1982.

Greenstein, A.L. Signs Used by Pupils in an Oral Residential School for the Deaf. Unpublished Thesis, University of the Witwaterrand, Johannesburg, 1983.

Klima, E. and Bellugi, U. The Signs of Language. Harvard University Press, Massachusetts, 1980.

Lewis, R.E. An Overview of the Research into the American Sign Language Continuum and its Relevance to South African Sign Languages and Codes. An Unpublished Paper, University of the Witwatersrand, Johannesburg, 1983.

Markowicz, H. Some Sociolinguistic Considerations of American Sign Language. In: W.C. Stokoe. Sign and Culture. Linstok Press, Maryland, 1980.

Musselwhite, C.R. and St. Louis, K. Communication Programming for the Severely Handicapped: Vocal and Non-Vocal Strategies. College Hill Press, Houston, Texas, 1982.

Nieder-Heitmann, N. Talking to the Deaf. Government Press, Pretoria, 1980.

Orlansky, M.D. and Bonvillian, J.D. The Role of Iconicity in Early Sign Language Acquisition. Journal of Speech and Hearing Disorders, Vol. 49, 287-292, 1984. 
Penn, C. Lewis, R. and Greenstein, A. Sign Language in South Africa: Some Research and Clinical Issues. South African Journal of Communication Disorders, Vol 31, 6-11, 1984.

Rousseau, G.J. Foreword. In: N. Nieder-Heitmann. Talking to the Deaf. Government Press, Pretoria, 1980.

Siple, P., Hatfield, N. and Caccamise, F. The Role of Visual Perceptual Abilities in the Acquisition and Comprehension of Sign Language. American Annals of the Deaf. Nov. 78, 852856, 1978a.

Siple, P. Linguistic and Psychological Properties of American
Sign Language: An Overview. In: P Siple (Ed.) Perspectives in Newrolinguistics and Psycholinguistics. A Series of Monographs and Treatises. Academic Press, Inc., New York, 1978b.

Stokoe, W.C. Sign and Culture. Linstok Press, Maryland, 1980a. Stokoe, W.C. The Study and Use of Sign Language. In: R.L. Schiefelbusch. Language Intervention. University Park Press, Baltimore, 1980b.

Warren, S. Signed lexical items in an Afrikaans oral residential school for the Deaf. Unpublished BLog Thesis, University of Pretoria, Pretoria, 1985.

Appendix: A description of the signs used by the majority of subjects in the Afrikaans and English schools respectively together with a representation of the South African signs.

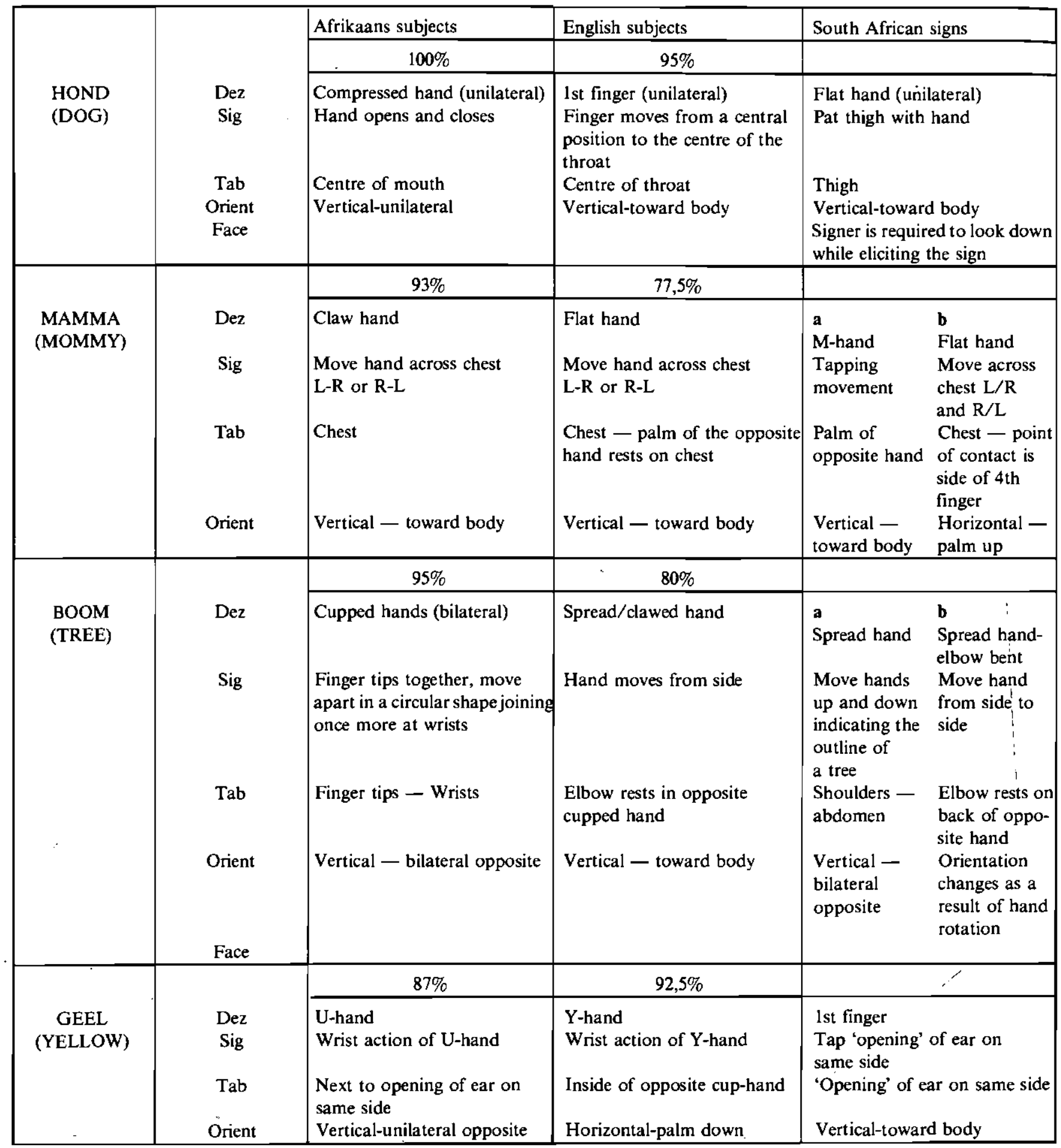




\begin{tabular}{|c|c|c|c|c|}
\hline \multirow[b]{3}{*}{$\begin{array}{l}\text { OUD* } \\
\text { (OLD) }\end{array}$} & \multirow[b]{3}{*}{$\begin{array}{l}\text { Dez } \\
\text { Sig } \\
\text { Tab } \\
\text { Orient } \\
\text { Face } \\
\end{array}$} & Afrikaans subjects & English subjects & South African signs \\
\hline & & $80 \%$ & $92,5 \%$ & \\
\hline & & $\begin{array}{l}\text { Crooked finger } \\
\text { Move finger slowly down cheek } \\
\text { Cheek on same side } \\
\text { Vertical-palm away from body }\end{array}$ & & \\
\hline \multirow[b]{2}{*}{$\begin{array}{c}\text { BLY } \\
\text { (HAPPY) }\end{array}$} & \multirow[b]{2}{*}{$\begin{array}{l}\text { Dez } \\
\text { Sig } \\
\text { Tab } \\
\text { Orient } \\
\text { Face }\end{array}$} & $57 \%$ & $92,5 \%$ & \\
\hline & & $\begin{array}{l}\text { Flat hands (bilateral) } \\
\text { Clap hands together } \\
\text { Neutral region (Abdomen) } \\
\text { Vertical-bilaterial opposite } \\
\text { Happy look }\end{array}$ & $\begin{array}{l}\text { Flat hands (bilateral) } \\
\text { Clap hands together } \\
\text { Abdominal region } \\
\text { Vertical-appears bilateral } \\
\text { opposite } \\
\text { Smile - happy look } \\
\end{array}$ & $\begin{array}{l}\text { Flat hands (bilateral) } \\
\text { Clap hands together } \\
\text { Abdominal region } \\
\text { Horizontal - palm down } \\
\text { and up } \\
\text { Smile - happy look }\end{array}$ \\
\hline \multirow[b]{2}{*}{$\begin{array}{c}\text { BAD } \\
\text { (BATHING) }\end{array}$} & \multirow[b]{2}{*}{$\begin{array}{l}\text { Dez } \\
\text { Sig } \\
\text { Tab } \\
\text { Orient } \\
\text { Face } \\
\end{array}$} & $95 \%$ & $80 \%$ & \\
\hline & & $\begin{array}{l}\text { Spread hand-unilateral } \\
\text { Rub hand in circular motion } \\
\text { Lower chest-abdomen } \\
\text { Vertical-toward body }\end{array}$ & $\begin{array}{l}\text { Spread hand-unilateral } \\
\text { Rub hand up and down } \\
\text { Chest-Abdomen } \\
\text { Vertical-toward body }\end{array}$ & $\begin{array}{l}\text { Clawed fists (bilateral) } \\
\text { Rub hand up and down } \\
\text { Chest region } \\
\text { Vertical-toward body }\end{array}$ \\
\hline \multirow[b]{2}{*}{$\begin{array}{l}\text { SPRING } \\
\text { (JUMP) }\end{array}$} & & $72,5 \% \quad 15 \%$ & $35 \% \quad 35 \%$ & \\
\hline & $\begin{array}{l}\text { Dez } \\
\text { Sig } \\
\text { Tab } \\
\text { Orient } \\
\text { Face }\end{array}$ & $\begin{array}{|ll|}\text { a } & \text { b } \\
\text { V hand } & \text { Flat hands } \\
\text { Raised hand } & \text { Flat hands } \\
\text { once, verti- } & \text { are raised up- } \\
\text { cally from } & \text { wards. Jump } \\
\text { palm of oppo- } & \text { up and down } \\
\text { site hand } & \text { (lower limbs) } \\
\text { Palm of } & \\
\text { opposite hand } & \\
& \\
\text { Vertical- } & \text { Horizontal- } \\
\text { toward body } & \text { palms down } \\
\end{array}$ & 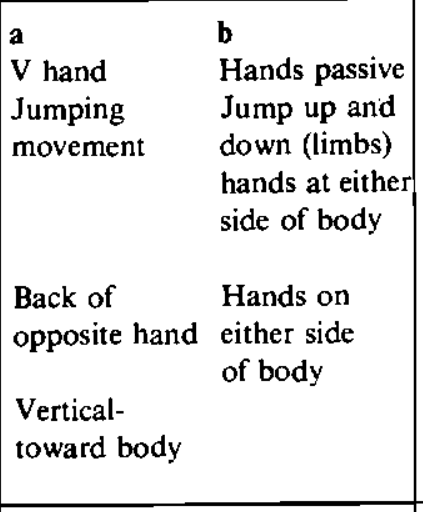 & $\begin{array}{l}\text { V hand } \\
\text { Raise hand vertically from } \\
\text { palm of opposite hand } \\
\text { Palm of opposite hand } \\
\text { Vertical-toward body }\end{array}$ \\
\hline \multirow[b]{2}{*}{$\begin{array}{c}\text { SIT } \\
(\text { SITIING) }\end{array}$} & & $77,5 \%$ & $52,5 \% \quad 22,5 \%$ & \\
\hline & $\begin{array}{l}\text { Sig } \\
\text { Tab } \\
\text { Orient } \\
\text { Face }\end{array}$ & 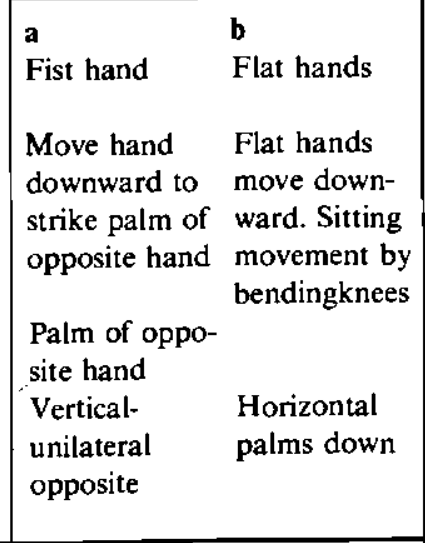 & 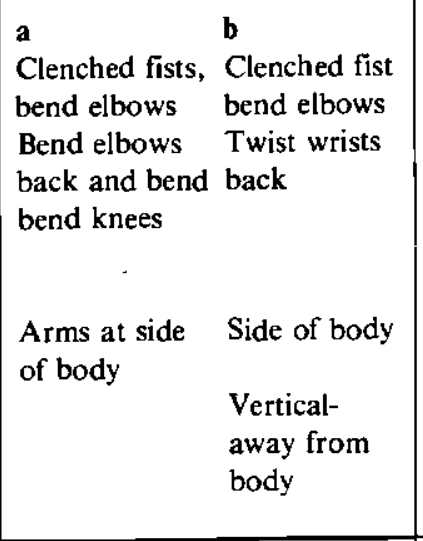 & $\begin{array}{l}\text { Clenched fists - Open thumb } \\
\text { Close fist by pushing down } \\
\text { thumb } \\
\text { Side of body } \\
\text { Vertical - Bilateral opposites }\end{array}$ \\
\hline \multirow[b]{2}{*}{$\begin{array}{c}\mathrm{OP} \\
\text { (UP) }\end{array}$} & \multirow[b]{2}{*}{$\begin{array}{l}\text { Dez } \\
\text { Sig } \\
\text { Tab } \\
\text { Orient } \\
\text { Face }\end{array}$} & $72 \%$ & $50 \%$ & \\
\hline & & $\begin{array}{l}\text { Flat hand } \\
\text { Move hand straight down } \\
\text { Neutral- abdomen } \\
\text { Horizontal - palm down }\end{array}$ & $\begin{array}{l}\text { Palm of flat hand } \\
\text { Clap palms together } \\
\text { Palm of opposite flat hand } \\
\text { Horizontal - palm down }\end{array}$ & $\begin{array}{l}\text { Palm of flat hand } \\
\text { Clap palm of flat hand on } \\
\text { back of opposite hand } \\
\text { Back of opposite flat hand } \\
\text { Horizontal - palm down }\end{array}$ \\
\hline
\end{tabular}

*The only South African sign consistently used by English and Afrikaans subjects. 


\begin{tabular}{|c|c|c|c|c|c|}
\hline \multirow[b]{3}{*}{$\begin{array}{l}\text { VOOR } \\
\text { In front } \\
\text { of) }\end{array}$} & \multirow[b]{3}{*}{$\begin{array}{c}\text { Dez } \\
\text { Sig } \\
\\
\text { Tab } \\
\text { Orient }\end{array}$} & \multicolumn{2}{|c|}{ Afrikaans subjects } & \multirow{2}{*}{$\begin{array}{l}\text { English subjects } \\
\text { Variations }\end{array}$} & \multirow[t]{2}{*}{ South African signs } \\
\hline & & $42 \%$ & $35 \%$ & & \\
\hline & & $\begin{array}{l}\text { a } \\
\text { Cupped } \\
\text { hand } \\
\text { Move hand } \\
\text { forward in } \\
\text { semi-circle } \\
\text { away from } \\
\text { chest } \\
\\
\text { Chest neutral } \\
\text { Vertical- } \\
\text { toward } \\
\text { body }\end{array}$ & $\begin{array}{l}\text { b } \\
1 \text { finger } \\
\text { Point } \\
\text { finger for- } \\
\text { ward. Wrist } \\
\text { of dominant } \\
\text { hand strikes } \\
\text { wrist of oppo- } \\
\text { site hand } \\
\text { Wrists } \\
\text { Vertical- } \\
\text { away from } \\
\text { body }\end{array}$ & $\begin{array}{l}\text { Extreme variation within } \\
\text { this sign }\end{array}$ & $\begin{array}{l}\text { Compressed hand } \\
\text { Move hand across chest } \\
\text { L-R or R-L }\end{array}$ \\
\hline \multirow[b]{2}{*}{$\begin{array}{l}\text { NA...TOE } \\
\text { (TO) }\end{array}$} & & $50 \%$ & $20 \%$ & $87 \%$ & \\
\hline & $\begin{array}{l}\text { Tab } \\
\text { Orient } \\
\text { Face }\end{array}$ & $\begin{array}{l}\text { a } \\
\text { lst finger } \\
\text { bilateral } \\
\text { Move lst } \\
\text { finger of } \\
\text { dominant } \\
\text { hand along } \\
\text { side of } \\
\text { opposite } \\
\text { lst finger } \\
\text { Side of } \\
\text { opposite } \\
\text { finger } \\
\text { Horizontal } \\
\text { palm down }\end{array}$ & $\begin{array}{l}\text { In front } \\
\text { Vertical- } \\
\text { unilateral } \\
\text { opposite }\end{array}$ & In front or $L ; R$ & $\begin{array}{l}\text { 1st finger of opposite hand } \\
\text { centre of body } \\
\text { Vertical-palm away } \\
\text { from body }\end{array}$ \\
\hline
\end{tabular}

\title{
The Use of Signs and the Coding of Prefix Markers by Teachers at a School for the Deaf
}

\author{
Myrtle L Aron, $\mathrm{Ph} \mathrm{D}$ (Witwatersrand)
}

\author{
Robyn E Lewis, BA(Log.) (Witwatersrand) BA Soc.Science (UNISA) \\ Judy L Willemse, BA (Sp. \& H Therapy) (Witwatersrand) \\ Department of Speech Pathology and Audiology \\ University of the Witwatersrand, Johannesburg
}

\begin{abstract}
The use of aspects of an artificially devised manual code in a black school for the deaf was examined. The encoding of prefixes, bound with the noun class system, in Tswana as used by seven teachers was studied as well as the consistency of the teachers to code lexical items. Results indicated the absence of signed prefix markers, inconsistency in signing lexical items and much variability among teachers in the signs used. The educational and research implications are discussed.

\section{OPSOMMING}

Die gebruik van aspekte van 'n kunsmatig ontwikkelde gebarestelsel in 'n swart skool vir dowes, is ondersoek. Die enkodering van voorvoegsels verbonde aan die naamwoordklasstelsel in Tswana soos gebruik deur sewe onderwysers is bestudeer, asook die konstantheid van die onderwyser se vermoë om leksikale items te kodeer. Resultate dui op die afwesigheid van voorvoegselgebare, onkonstantheid van leksikale gebare en baie variasie onder onderwysers t.o.v. die gebare wat hulle gebruik. Die opvoedkundige en navorsingsimplikasies word bespreek.
\end{abstract}

